\title{
ISYARAT EKSTERNAL DAN INTERNAL PENGARUHNYA TERHADAP PERILAKU PEMBELIAN IMPULSIF MAHASISWA
}

\author{
Retno Dewi Wijiastuti \\ Universitas Muhammadiyah Sorong
}

Diterima:19 Oktober 2016. Disetujui:28 November 2016. Dipublikasikan:1 Desember 2016

\begin{abstract}
ABSTRAK
Pasar bersifat dinamis dan selalu berubah mengakibatkan bertambahnya minat dalam beberapa area perilaku konsumen termasuk di dalamnya pembelian impulsif. Beberapa penelitian menyatakan bahwa lebih dari $50 \%$ konsumen yang berbelanja di mall membeli item produk secara impulsif dan sebanyak $70 \%$ dari semua item produk pada toko bahan makanan dan minuman dibeli secara impulsif, kemudian diperkirakan lebih dari 4 Miliar US\$ penjualan tahunan di Amerika Serikat terjadi melalui pembelian impulsif, sehingga hal ini tentu saja akan berdampak pada naiknya laba perusahaan. Tujuan penelitian ini adalah untuk mengetahui pengaruh isyarat eksternal yaitu stimulus marketing mix, atmosfer dalam retail dan isyarat internal yaitu impulse buying tendency (IBT) atau kecenderungan pembelian impulsif, afektif, kognitif dan evaluasi normatif terhadap perilaku pemblian impulsif yang dilakukan oleh kalangan mahasiswa di kota Malang.

Data dikumpulkan melalui penyebaran kuisioner dan wawancara yang dilakukan terhadap 150 responden mahasiswa Universitas Brawijaya (UB) Malang dan Universitas Muhammadiyah Malang (UMM). Alat analisis yang digunakan untuk menjawab hipotesis dalam penelitian ini adalah analisis regresi berganda. Hasil penelitian menunjukkan bahwa isyarat eksternal dan internal berpengaruh signifikan pada pembelian impulsif. Stimulus marketing mix, IBT, afektif, kognitif dan evaluasi normatif mampu meningkatkan level pembelian impulsif yang dilakukan kalangan mahasiswa di kota Malang. Hasil lainnya menunjukkan bahwa kognitif berbanding terbalik atau negatif terhadap pembelian impulsif. Dengan kata lain semakin tinggi aspek kognitif seseorang, semakin menurunkan perilaku pembalian impulsif. Tetapi tidak ditemukan pengaruh signifikan atmosfer dalam retail terhadap pembelian impulsif, artinya tinggi atau rendahnya strategi atmosfer dalam retail yang sengaja diciptakan oleh pihak pemasar dan retailer tidak akan berdampak pada level pembelian impulsif yang dilakukan oleh kalangan mahasiswa di kota Malang.
\end{abstract}

Kata Kunci : Pembelian impulsif, stimulus marketing mix, atmosfer dalam retail impulse

\section{PENDAHULUAN} buying tendency (IBT), afektif, kognitif dan evaluasi normatif.

\subsection{Latar Belakang}

Pasar bersifat dinamis dan selalu berubah, salah satu perubahan yang saat ini sedang terjadi adalah ketika industri beralih dari pemasaran massal ke era penyesuaian massal. Akibat dari gelombang ini adalah bertambahnya minat dalam beberapa area perilaku konsumen termasuk didalamnya pembelian impulsif (Foreman, 1999). Diperkirakan lebih dari 4 Miliar US\$ penjualan tahunan di Amerika Serikat terjadi melalui pembelian impulsif (E.J. Park,
2006), dan tidak menutup kemungkinan perkembangan fenomena ini dapat terjadi di negara-negara berkembang seperti Indonesia.

Retailer sangat sadar bahwa bagian volume penjualan yang cukup besar dibangkitkan oleh sifat pembelian impulsif, dimana lebih dari sepertiga di seluruh pembelian pada Department Store dilakukan secara impulsif (Bellenger et al., 1978), kemudian lebih dari $50 \%$ orang yang berbelanja di mall membeli item produk secara impulsif dan sebanyak $70 \%$ dari 
semua item produk toko bahan makanan dan minuman dibeli secara impulsif (Coley dan Burgess, 2003), sehingga hal ini tentu saja akan berdampak pada naiknya laba perusahaan. Namun bila dilihat dari sisi konsumen seringkali pembelian impulsif secara khusus berhubungan dengan problem keuangan pasca pembelian, produk mengecewakan, perasaan bersalah, dan ketidaksetujuan sosial.

Perilaku pembelian impulsif merupakan salah satu bentuk pembelian dimana proses pembelian barang terjadi secara spontan (Hendri Ma'ruf, 2005).. Banyak penelitian yang menyatakan bahwa perilaku pembelian ini termasuk dalam perilaku pembelian yang negatif. Akan tetapi walaupun perilaku pembelian impulsif ini diasosiasikan sebagai perilaku negatif, beberapa penelitian menyatakan bahwa hampir 90\% konsumen menyatakan pernah membeli secara impulsif, dan sekitar 30-50\% pembelian diklasifikasikan oleh pembeli sendiri sebagai pembelian impulsif (Welles dalam Hausman, 2000).

Youn dan Feber (2000) menyatakan bahwasannya terdapat pengaruh variabel eksternal terhadap pembelian impulsif. Pemicu eksternal yaitu, pertama atmosfer dalam lingkungan retail (misalnya tampilan toko dan musik) dan kedua isyarat bauran pemasaran marketing mix (harga, promosi dan iklan) juga adalah pemicu penting yang dapat mempengaruhi keinginan untuk membeli secara impulsif (Youn dan Feber, 2000).

Selain dipengaruhi oleh variabel eksternal, Dawson dan Kim (2009) dan Rook dan Fisher (1995) menyatakan bahwa variabel internal juga merupakan variabel yang melatarbelakangi munculnya perilaku pembelian impulsive. Variabel internal ini berhubungan dengan karakteristik kepribadian dan emosional dari setiap individu. Variabel internal dalam pembelian impulsif seperti kecenderungan pembelian impulsif atau impulse buying tendency (IBT), afektif, kognitif dan evaluasi normatif.
Kecenderungan pembelian impulsif atau impulse buying tendency (IBT) merupakan variabel internal yang berhubungan dengan ciri-ciri kepribadian di mana pembeli impulsif kekurangan kontrol kognitif atau kurangnya proses berpikir untuk tidak melakukan pembelian impulsif (Youn dan Faber 2000).

Afektif yang merupakan variabel internal pembelian impulsif berfokus kepada perasaan diri konsumen, mood dan keadaan emosional yang membuat mereka melakukan pembelian impulsif. Kognitif yang merupakan bagian dari variabel internal diartikan sebagai proses berpikir, proses pemahaman dan penafsiran yang dilakukan oleh konsumen terhadap sebuah informasi (Youn, 2000). Sebuah studi menyimpulkan meskipun kesengajaan kognitif memainkan peran dalam keputusan pembeli impulsif, namun pengaruhnya lebih kecil daripada pengaruh yang didapat dari keadaan afektif (Weinberg dan Gottwald dalam Coley dan Burgess, 2003). Selanjutnya evaluasi normatif juga merupakan variabel internal yang tidak dapat diabaikan dalam mengkaji perilaku pembelian impulsif. Evaluasi normatif yaitu keputusan konsumen tentang ketepatan melakukan pembelian impulsif dalam situasi pembelian khusus (Rook dan Fisher, 1995).

Berdasarkan uraian-uraian di atas, dapat disimpulkan bahwa terdapat enam variabel yang mendorong seseorang untuk berperilaku impulsif dalam berbelanja yakni : variabel eksternal meliputi stimulus marketing mix dan atmosfer dalam retail sedangkan variabel internal meliputi kecenderungan pembelian impulsif (IBT), afektif, Kognitif, dan evaluasi normatif. Namun pada penelitian-penelitian yang telah disebutkan di atas hanya dititikberatkan pada variabel yang melatarbelakangi pembelian impulsive ataupun hanya menghubungkan variable tersebut dengan pembelian impulsive, bukan dengan menguji keberadaan variabel eksternal dan internal yang dapat 
meningkatkan dan mempengaruhi perilaku pembelian impulsive.

Studi ini pada dasarnya merupakan penelitian replikasi ekstensi didasarkan pada penelitian terdahulu yang dilakukan oleh Dawson dan Kim (2009). Penelitian replikasi ekstensi yaitu penelitian yang memperluas hipotesis-hipotesis yang telah dikembangkan oleh peneliti lain untuk menghasilkan sebuah model baru yang lebih lengkap atau lebih menyeluruh atau lebih fokus dengan beberapa hipotesis (Ferdinand, 2006). Penelitian Dawson dan Kim (2009) sendiri bertujuan untuk menyelidiki pembelian impulsif internal dan eksternal konsumen pada saat melakukan aktivitas belanja online melalui media internet.

Penelitian Dawson dan Kim (2009) memiliki keterbatasan yang dapat pula dijadikan research gap dalam penelitian ini.. Penelitian Dawson dan Kim (2009) tidak menunjukkan efek atau pengaruh dari isyarat eksternal terhadap perilaku pembelian impulsif secara online, sedangkan dalam penelitian sebelumnya yang dilakukan oleh Youn dan Feber (2000) dan Dholakia (2000) menunjukkan hasil sebaliknya dimana isyarat eksternal ini mempengaruhi perilaku pembelian impulsif. Adanya hasil penelitian yang berbeda atau research gap mengenai pengaruh variabel eksternal dalam pembelian impulsif menjadikan fenomena ini menarik untuk diteliti secara lebih mendalam dengan menguji kembali keberadaan variabel eksternal dan pengaruhnya terhadap pembelian impulsif.

Perbedaan penelitian ini dengan penelitian yang dilakukan oleh Dawson dan Kim (2009) adalah, fokus pembelian impulsif dalam penelitian ini menggunakan format toko dan retail bukan pada media online (internet), variabel eksternal yang digunakan diadopsi dari Youn dan Feber (2000) yaitu stimulus marketing mix dan atmosfer dalam retail, responden dalam penelitian ini yaitu mahasiswa laki-laki dan perempuan, dan mengkaitkan pembelian impulsif dengan beberapa kategori produk pembelian.
Penelitian ini juga secara khusus mengkaitkan variabel-variabel eksternal dan intenal sebagai pemicu terjadinya perilaku pembelian impulsif pada kategori produk tertentu, karena beberapa kategori produk lebih sering dibeli secara impulsif oleh konsumen dibandingkan produk yang lainnya (Coley dan Burgess, 2003). Berkenaan dengan hal tersebut penelitian ini mencoba untuk meneliti perilaku pembelian impulsif terhadap lima katergori produk yang cenderung dibeli secara impulsif yaitu fashion product atau produk fashion (pakaian, sepatu, topi, tas), food and beverage atau makanan dan minuman, books and stationery atau buku dan perlengkapan tulis menulis, body care items atau item-item perawatan tubuh (sabun, shampo, make-up, parfum) dan music items atau item-item musik (kaset, CD, dan DVD) (Coley dan Burgess, 2003; Bellenger et al., 1978).

Meneliti mengenai pembelian impulsif di kota Malang, tentu saja hal ini berkaitan dengan keberadaan mahasiswa sebagai salah satu kelompok target pasar potensial terbesar bagi pemasar, data yang tercatat di pemkot Malang (2009) menyatakan bahwa setiap tahunnya kota Malang menerima pendatang baru yang sebagian besar merupakan mahasiswa. Mahasiswa jenjang Strata satu (S1) dengan rentang usia 17-25, mahasiswa mempunyai minat yang cukup besar pada penampilan diri, uang, indikasi status sosial, cara berpakaian dan daya tarik, sehingga kecenderungan kelompok ini untuk melakukan aktivitas belanja lebih besar dibandingkan dengan orang yang lebih tua demi memenuhi kebutuhan tersebut (Weekes, 2004)..

Dalam penelitian ini ada dua perguruan tinggi yang dijadikan objek penelitian, yaitu: Universitas Brawijaya (UB) yang mempresentasikan perguruan tinggi negeri terbesar di kota Malang dan Universitas Muhammadiyah Malang (UMM) yang mempresentasikan perguruan 
tinggi swasta terbesar di kota Malang. UB menempati urutan pertama perguruan tinggi negeri terbesar di kota Malang dengan jumlah mahasiswa mencapai 27.461 (sumber: http://www.brawijaya.ac.id), sedangkan UMM merupakan perguruan tinggi swasta terbesar di kota Malang dengan jumlah mahasiswa mencapai 21. 907 (sumber: http://www.umm.ac.id).

Berdasarkan uraian yang telah dipaparkan diatas baik secara empirik atupun teoritik, maka muncul pertanyaan baru dalam penelitian ini yaitu: Bagaimanakah pengaruh variabel eksternal yaitu stimulus marketing mix dan atmosfer dalam retail, kemudian variabel internal yang meliputi kecenderungan pembelian impulsif atau impulse buying tendency (IBT), afektif, kognitif dan evaluasi normatif terhadap perilaku pembelian impulsif yang dilakukan oleh kalangan mahasiswa di kota Malang?. Oleh karena itu judul yang diajukan dalam penelitian ini adalah: "Isyarat Eksternal dan Internal: Pengaruhnya Terhadap Perilaku Pembelian Impulsif Mahasiswa di Kota Malang".

\subsection{Tujuan Penelitian}

1. Untuk mengetahui signifikansi pengaruh variabel isyarat eksternal (stimulus marketing mix dan atmosfer dalam retail) dan isyarat internal (kecenderungan pembelian impulsif (IBT), afektif, kognitif, dan evaluasi normative) secara simultan terhadap perilaku pembelian impulsif mahasiswa.

2. Untuk mengetahui signifikansi pengaruh variabel isyarat eksternal (stimulus marketing mix dan atmosfer dalam retail) dan isyarat internal (kecenderungan pembelian impulsif (IBT), afektif, kognitif, dan evaluasi normative) secara parsial terhadap perilaku pembelian impulsif mahasiswa.

3. Untuk mengetahui variabel mana, diantara isyarat eksternal (stimulus marketing mix dan atmosfer dalam retail) dan isyarat internal (kecenderungan pembelian impulsif (IBT), afektif, kognitif, dan evaluasi normative) yang berpengaruh dominan terhadap perilaku pembelian impulsif mahasiswa.

\section{METODE PENELITIAN}

\subsection{Jenis Penelitian}

Penelitian ini sendiri termasuk dalam jenis penelitian penjelasan (explanatory research). Peneletian eksplanatory adalah penelitian yang bermaksud menjelaskan kedudukan variable-variabel yang diteliti serta hubungan antara satu variable dengan variable yang lain (Sugiyono, 2002).

Sedangkan pendekatan penelitian yang digunakan adalah penelitian kuantitatif, dimana metode kuantitatif merupakan metodologi yang berupaya untuk mengkuantifikasi data, dan biasanya, menerapkan analisis statistik tertentu (Maholtra, 2005).

\subsection{Tempat dan Waktu Penelitian}

Penelitian ini dilakukan di Universitas Brawijaya (UB) yang terletak di Jl. Veteran Malang dan Universitas Muhammadiyah Malang (UMM) yang terletak di Jl. Raya Tlogomas Malang. Sedangkan waktu pelaksanaan penelitian ini dilakukan pada bulan November 2009.

\subsection{Desain Sampling Penelitian}

\subsubsection{Populasi dan Sampel Penelitian}

Adapun karakteristik individu populasi target pada penelitian ini adalah :

1. Seluruh mahasiswa Universitas Brawijaya (UB) dan Universitas Muhammadiyah Malang (UMM) di kota Malang.

2. Mahasiswa jenjang Strata Satu (S1) UB dan UMM yang pernah melakukan pembelian impulsif minimal satu kali.

3. Mahasiswa S1 dengan jenjang usia 17-25 tahun berada pada tahapan usia remaja dan dewasa. 
Berbagai hal di atas semakin memperkuat pelibatan mahasiswa S1 UB dan UMM sebagai populasi target dalam peneliatian ini. Selanjutnya dari populasi target tersebut, diadakan pengambilan sampel. Berdasarkan karakteristik populasi target di atas, maka sampel dalam penelitian ini adalah mahasiswa S1 UB dan UMM di kota Malang yang pernah melakukan pembelian impulsif minimal satu kali, dengan besarnya uang saku yang diterima masing-masing mahasiswa \pm $600.000 \mathrm{rupiah} / \mathrm{bln}$.

Selanjutnya alasan dipilihnya mahasiswa S1 UB dan UMM sebagai sampel dalam penelitian ini karena kedua perguruan tinggi tersebut mewakili jumlah mahasiswa perguruan tinggi negeri dan swasta terbesar di kota Malang dibandingkan dengan perguruan tinggi lainnya.

\subsubsection{Ukuran Sampel}

Terkait dengan besarnya jumlah ukuran populasi $(\mathrm{N})$ yang tidak diketahui secara pasti atau tidak terukur, maka pedoman bagi peneliti untuk menentukan sampel dalam penelitian ini merujuk pada Sekaran (dalam Ferdinand, 2006), dimana penelitian multivariate (termasuk yang menggunakan analisis regresi multivariant) besarnya sampel yang ideal dapat ditentukan sebanyak 25 dikalikan dengan jumlah variabel/ sub variabel independen.

Berdasarkan pendapat di atas, ditetapkan responden sebesar 150 orang yang didapatkan dari perkalian antara 25 ukuran sampel yang ideal dengan jumlah enam (6) variabel independen, sehingga diperoleh $25 \quad$ x 6 (jumlah variabel independen $)=150$ orang reponden.

\subsubsection{Teknik Pengambilan Sampel}

Pengambilan sampel penelitian menggunakan teknik sampling non probabilitas dimana tidak semua elemen populasi memiliki kesempatan yang sama untuk terpilih menjadi sampel penelitian. Adapun teknik non probabilitas yang dipilih dalam penelitian ini adalah purposive sampling (Judgement sampling), dimana peneliti secara sadar memilih sampel penelitian yang dianggap paling sesuai untuk dilibatkan dalam penelitian.

\subsection{Metode Pengumpulan Data \\ 4.4.1. Jenis dan Sumber Data}

Sumber data dalam penelitian adalah subyek atau objek darimana data dapat diperoleh. Terdapat dua sumber data dalam penelitian ini, yaitu :
a. Data primer
b. Data sekunder

\subsubsection{Teknik Pengumpulan Data}

Teknik pengumpulan data yang digunakan dalam penelitian ini yaitu penyebaran kuesioner dan wawancara (interview) untuk memperkecil bias penelitian.
a. Kuesioner
b.Wawancara

\subsection{Skala dan Pengukuran data}

Pengukuran data kuesioner yang berkaitan dengan variabel bebas maupun terikat dengan menggunakan skala likert. Umumnya masing-masing item scale mempunyai lima kategori, yang berkisar antara angka 1 (untuk jawaban "sangat tidak setuju") hingga 5 (untuk jawaban "sangat setuju").

\subsection{Uji Instrumen Data}

\subsubsection{Uji Validitas}

Teknik pengujiannya dengan menggunakan teknik korelasi product moment Pearson, dan menggunakan tingkat signifikansi sebesar 5\%.

\subsubsection{Uji Reliabilitas}

Dengan menggunakan software SPSS 12,0 for windows untuk mengukur reliabilitas dengan uji statistik Cronbach Alpha $(\alpha)$. Jika lebih dari 0,60 maka kuesioner tersebut reliable (Ghozali, 2006).

\subsection{Metode Analisis Data}

\subsubsection{Analisis Deskriptif}

Analisis statistik deskriptif digunakan untuk memberikan gambaran atau deskripsi 
empiris atas data yang dikumpulkan dalam penelitian (Ferdinand, 2006).

\subsubsection{Analisis Statistik Inferensial}

Untuk menguji hipotesis, digunakan uji statistik analisis regresi berganda, analisis ini digunakan untuk melihat signifikansi pengaruh variable independen dan dependen. Model regresi berganda yang digunakan dalam penelitian ini adalah:

$Y=\alpha+\beta_{1} X_{1}+\beta_{2} X_{2}+\beta_{3} X_{3}+\beta_{4} X_{4}+\beta_{5} X_{5}+$ $\beta_{6} \mathrm{X}_{6}+\mathrm{e}$

\section{Keterangan}

Y : Variabel dependen (Pembelian impulsif)

$\alpha \quad$ : Konstanta

$\beta_{1} \ldots \beta_{6}$ : Koefisien regresi yang digunakan untuk menjelaskan pengaruh sebuah variabel independen terhadap variabel dependen

$\mathrm{X}_{1} \quad$ : Stimulus marketing mix

$\mathrm{X}_{2} \quad$ : Atmosfer dalam retail

$\mathrm{X}_{3} \quad$ : Impulse buying tendency (IBT) atau kecenderungan pembelian impulsive

$\mathrm{X}_{4} \quad$ : Afektif

$\mathrm{X}_{5} \quad$ : Kognitif

$\mathrm{X}_{6} \quad$ : Evaluasi normatif

e : Gangguan acak

\subsubsection{Uji Asumsi Klasik}

\subsubsection{Uji Multikolonieritas}

Uji multikolonieritas digunakan untuk menguji apakah pada model regresi ditemukan adanya korelasi antar variabel independen.

\subsubsection{Uji Heteroskedastisitas}

Uji heteroskedastisitas bertujuan untuk menguji apakah dalam model regresi terjadi ketidaksamaan variance dari residual satu pengamatan ke pengamatan yang lain.

\subsubsection{Uji Normalitas}

Uji normalitas bertujuan untuk menguji apakah dalam model regresi, variabel pengganggu atau residual memiliki distribusi normal. Uji $t$ dan uji $\mathrm{F}$ mengasumsikan bahwa nilai residual mengikuti distribusi normal.).

\subsection{Pengujian Hipotesis}

Untuk membuktikan hipotesis dengan menggunakan model regresi linier berganda, maka diperlukan pengujian terhadap model dengan menggunakan:

- Koefisien determinasi $\left(\mathrm{R}^{2}\right)$, digunakan untuk mengetahui ketepatan model yang dipakai. Hal ini dinyatakan dengan berapa persen variabel dependen mampu dijelaskan oleh variabel-variabel independen yang dimasukan ke dalam model regresi.

Terkait dengan ketiga hipotesis penelitian, maka pengujian hipotesis dalam penelitian ini adalah sebagai berikut

1. Pengujian hipotesis pertama, Uji F.

2. Pengujian hipotesis kedua, Uji $t$ (partial test).

3. Pengujian hipotesis ketiga, Uji Koefisien beta (beta coefficient).

\section{HASIL DAN PEMBAHASAN}

\subsection{Karakteristik Responden}

Data penelitian diperoleh dari kuesioner yang telah didistribusikan kepada responden. Jumlah responden yang terlibat pada penelitian ini berjumlah 150 .

Karakteristik responden pada penelitian ini terdiri atas jenis kelamin, usia, jumlah uang saku perbulan dan asal perguruan tinggi dan fakultas. Gambaran karakteristik responden berikut ini merupakan sebuah representasi dari populasi yang ada. Sedangkan keragaman karakteristik responden bisa berperan menjadi sumber pembeda penilaian terhadap keenam variabel yang diteliti, yaitu stimulus marketing mix, atmosfer dalam retail, IBT, afektif, kognitif dan evaluasi normatif. Karakteristik responden menjadi pelengkap data dalam penelitian. 


\subsection{Hasil Uji Instrumen Data}

\subsubsection{Uji Validitas dan Reliabilitas}

Hasil uji validitas dan reliabilitas menjelaskan bahwa ke-43 butir pertanyaan adalah valid untuk mengukur variabel penelitian. Tingkat signifikansi (p-value) setiap koefisien korelasi Pearson bernilai kurang dari 0,05 menunjukkan adanya korelasi yang signifikan antara skor butir dengan skor total. Sedangkan untuk reliabilitasnya diketahui bahwa semua variabel penelitian yakni variabel stimulus marketing mix, atmosfer dalam retail, kecenderungan pembelian impulsif (IBT), afektif, kognitif, evaluasi normatif dan pembelian impulsif memiliki tingkat kehandalan instrumen yang diukur dengan metode Alpha Cronbach dan seluruhnya dihasilkan koefisien dengan nilai lebih dari 0,60 .

\subsection{Deskripsi Variabel Penelitian}

Variabel penelitian ini terdiri atas 7 variabel utama. Pengukuran diberikan dengan rentang jawaban tertutup pada skala $1-5$. Pada setiap item pertanyaan responden diminta untuk dapat memberikan penilaian sikap terhadap pernyataan-pernyataan yang ada. Deskripsi setiap variabel dilakukan terhadap seluruh item pertanyaan baik dari sisi nilai rata-rata variabel dan item maupun proporsi tiap skor jawaban.

\subsection{Pemeriksaan Asumsi Hasil Analisis Regresi}

\section{Asumsi Non Multikolinieritas}

Hasil pemeriksaan terhadap asumsi tidak terjadi multikolinier dilakukan dengan menghitung Motivasi Variance Inflation Factor (VIF) pada variabel bebas. Gujarati (2005) berpendapat bahwa sebuah variabel bebas akan dianggap memiliki multikolinieritas yang tinggi dengan satu atau beberapa variabel bebas lainnya jika Motivasi VIF > 10. Dari hasil perhitungan dapat ditarik kesimpulan bahwa pada data tidak terjadi multikolinieritas karena seluruh Motivasi VIF yang didapat adalah kurang dari 10.

\section{Asumsi Non Heteroskedastisitas}

Heteroskedastisitas

akan mengakibatkan penaksiran koefisienkoefisien regresi menjadi tidak efisien. Hasil penaksiran akan menjadi kurang dari semestinya. Prosedur uji yang digunakan untuk mendeteksi gejala heteroskedastisitas adalah dengan uji Park. dari hasil yang ditunjukkan, dapat ditarik kesimpulan bahwa asumsi tidak terjadi heteroskedastisitas dapat terpenuhi.

\section{Uji Normalitas}

Pembuktian bahwa nilai residual (error) menyebar normal merupakan salah satu indikasi persamaan regresi yang diperoleh adalah baik. Pembuktian kenormalan nilai residual dilakukan dengan menggunakan uji Kolmogorov-Smirnov, yaitu dengan memperhatikan hasil nilai signifikansi (sig.Z) yang ada apakah lebih besar dari nilai $\alpha 0,05$. Hasil pengujian menunjukkan bahwa nilai signifikansi (sig.Z) adalah 0,929 dan nilai ini lebih besar dari $\alpha=0,05$ yang berarti asumsi normalitas terpenuhi. 
5.5. Hasil Analisis Regresi

\section{Persamaan Regresi}

\begin{tabular}{|c|c|c|c|c|c|}
\hline Variabel & $\begin{array}{c}\text { Koef. } \\
\text { Regresi }\end{array}$ & Beta & $\mathrm{T}$ & $\begin{array}{c}P- \\
\text { value }\end{array}$ & Ket \\
\hline Konstanta & -0.131 & & $\begin{array}{c}- \\
0.081\end{array}$ & 0.935 & \\
\hline $\mathrm{X} 1$ & 0.113 & 0.244 & 3.533 & 0.001 & Signifikan \\
\hline $\mathrm{X} 2$ & 0.048 & 0.049 & 0.749 & 0.455 & $\begin{array}{c}\text { Tdk } \\
\text { signifikan }\end{array}$ \\
\hline $\mathrm{X} 3$ & 0.191 & 0.166 & 2.640 & 0.009 & Signifikan \\
\hline $\mathrm{X} 4$ & 0.228 & 0.394 & 4.812 & 0.000 & Signifikan \\
\hline $\mathrm{X} 5$ & -0.435 & 0.334 & 6.247 & 0.000 & Signifikan \\
\hline X6 & $\begin{aligned} & 0.493 \\
= & \end{aligned}$ & 0.246 & 3.807 & 0.000 & Signifikan \\
\hline$t_{\text {tabel }}$ & $\begin{array}{l}1,977 \\
=\end{array}$ & & & & \\
\hline $\mathrm{R}$ & $\begin{array}{l}0,726 \\
=\end{array}$ & & & & \\
\hline R Square & $\begin{array}{l}0,528 \\
=\end{array}$ & & & & \\
\hline F hitung & $\begin{array}{l}26,624 \\
=\end{array}$ & & & & \\
\hline$P$-value & $\begin{array}{l}0,000 \\
=\end{array}$ & & & & \\
\hline $\mathrm{F}_{\text {tabel }}$ & 2,163 & & & & \\
\hline
\end{tabular}

Sumber. Hasil analisa data, 2009

Model regresi berdasarkan hasil analisis diatas, dengan melihat nilai koefisien Beta standardized adalah:

$Y=0,244 X_{1}+0,049 X_{2}+0,166 X_{3}+0,394 X_{4}-$ $0,334 X_{5}+0,246 X_{6}$

\section{Koefiesien Determinasi}

Berdasarkan perhitungan dapat diperoleh koefisien determinasi $\left(\mathrm{R}^{2}\right)$ sebesar 0,528 , artinya kemampuan persamaan regresi dalam memprediksi nilai variabel terikat adalah 52,8\%. Lebih lanjut nilai 52,8\% menunjukkan kontribusi dari stimulus marketing mix $\left(X_{1}\right)$, atmosfer dalam retail $\left(\mathrm{X}_{2}\right)$, impulse buying tendency (IBT) $\left(\mathrm{X}_{3}\right)$, afektif $\left(\mathrm{X}_{4}\right)$, kognitif $\left(\mathrm{X}_{5}\right)$ dan evaluasi normatif $\left(\mathrm{X}_{6}\right)$ mampu menjelaskan perubahan pembelian impulsif (Y) sebesar $52,8 \%$ sedangkan sisanya $47,2 \%$ dijelaskan oleh variabel lain yang tidak masuk dalam model persamaan regresi.

\section{Hasil Uji-F}

Pada awal pengujian, uji $F$ digunakan untuk mengetahui apakah variabel bebas (idependen )secara bersamasama (simultan) mempunyai pengaruh yang signifikan terhadap variabel terikat (dependen). Dari hasil perhitungan diperoleh $F$ hitung sebesar 26,624, sedangkan $F$ tabel $(6 ; 143)$ pada $\alpha=5 \%$ sebesar 2,163 (Tabel 5.19). Karena F hitung $>\mathrm{F}$ tabel, maka $\mathrm{H}_{0}$ ditolak dan $\mathrm{H}_{1}$ diterima.

\section{Hasil Uji-t}

Uji $\mathrm{t}$ digunakan untuk mengetahui apakah masing-masing variabel bebas secara parsial mempunyai pengaruh yang signifikan terhadap variabel terikat. Hasil menunjukkan bahwa ada lima dari enam variabel independen mempunyai pengaruh yang signifikan terhadap variabel dependen (Y).

\subsection{Pengujian Hipotesis}

\section{Pengujian Hipotesis Pertama}

Hipotesis pertama menyatakan bahwa secara bersama-sama variabel eksternal dan internal berpengaruh signifikan terhadap pembelian impulsif. Semakin tinggi stimulus marketing mix, atmosfer dalam retail, kecenderungan pembelian impulsif (IBT), afektif, kognitif, dan evaluasi normative semakin tinggi perilaku pembelian impulsif. Hipotesis ini berhubungan dengan hasil uji-F dalam analisis regresi. Hasil uji-F dengan dengan nilai $F=26,624$ dan $p$-value $=0,000$ memberikan kesimpulan bahwa secara simultan (bersama-sama) keenam variabel bebas berpengaruh signifikan terhadap 
pembelian impulsif sehingga data mendukung hipotesis pertama.

\section{Pengujian Hipotesis kedua}

Hipotesis kedua menyatakan bahwa masing-masing variabel eksternal dan internal berpengaruh signifikan terhadap pembelian impulsif. Semakin tinggi stimulus marketing mix, atmosfer dalam retail, kecenderungan pembelian impulsif (IBT), afektif, kognitif, dan evaluasi normative semakin tinggi perilaku pembelian impulsif. Hipotesis ini berhubungan dengan hasil uji-t dalam analisis regresi. Hasil uji-t terhadap koefisien regresi adalah signifikan kecuali pada variabel atmosfer dalam retail sehingga memberikan kesimpulan bahwa secara parsial variabel isyarat eksternal dan internal berpengaruh signifikan terhadap pembelian impulsif sehingga data mendukung hipotesis kedua.

\section{Pengujian Hipotesis Ketiga}

Hipotesis ketiga menyatakan bahwa variabel afektif dominan terhadap perilaku pembelian impulsif. Dominasi variabel bebas terhadap pembelian impulsif ditentukan oleh koefisien regresi yang telah distandarkan (koefisien beta). Koefisien beta terbesar adalah 0,394 dan berada pada variabel afektif (X4), sehingga data penelitian ini mendukung hipotesis ketiga.

\subsection{Pembahasan Hasil Penelitian}

5.7.1. Pengaruh Stimulus Marketing Mix, atmosfer dalam retail, IBT, Afektif, Kognitif dan Evaluasi Normatif

Jika strategi marketing mix (produk, harga, tempat dan promosi) ditingkatkan dan dirancang sedemikian rupa oleh pihak retailer maka kecenderungan konsumen untuk melakukan pembelian impulsif akan semakin meningkat.

Hasil penelitian ini secara empiris sesuai dengan penelitian terdahulu yang dilakukan oleh Youn dan Feber (2000) dan Dawson dan Kim (2009) yang menguji hubungan variabel eksternal dan internal terhadap pembelian impulsif.

\subsubsection{Pengaruh Stimulus marketing mix terhadap perilaku pembelian impulsif}

Berdasarkan penelitian yang telah dilakukan, diketahui bahwa jika strategi stimulus marketing mix dirancang dan ditingkatkan dengan tepat atau menarik oleh pihak pemasar, maka akan meningkatkan pembelian impulsif.

Hasil penelitian ini secara empiris mendukung penelitian sebelumnya yang dilakukan oleh Youn dan Feber (2000) dan Dawson dan Kim (2009) yang menghubungkan unsur-unsur marketing mix (produk, harga, tempat dan promosi) dengan peningkatan pembelian impulsif.

\subsubsection{Pengaruh Atmosfer Dalam Retail Terhadap Perilaku Pembelian Impulsif \\ Berdasarkan hasil penelitian yang} telah dilakukan dengan uji regresi berganda diketahui bahwa atmosfer dalam retail tidak berpengaruh signifikan terhadap perilaku pembelian impulsif.

Hasil penelitian ini secara empiris tidak sesuai dengan penelitian terdahulu yang dikemukakan oleh Youn dan Feber (2000) dan Coley dan Burgess (2003) yang menyatakan bahwa Suasana atau atmosfer adalah kunci untuk menarik dan mempertahankan konsumen yang sedang berbelanja, yang mungkin memicu kecenderungan afektif yang mengarahkan pada perilaku impulsif.

\subsubsection{Pengaruh IBT (Impulse Buying Tendency) atau Kecenderungan Pembelian Impulsif \\ Dari penelitian diperoleh hasil} bahwa IBT yang dimiliki seorang individu secara signifikan akan mempengaruhi pembelian impulsif.

Hasil penelitian ini secara empiris sesuai dengan temuan Beatty dan Ferrell (1998), Rook dan Fisher (1995), Dholakia (2000) dan Dawson dan Kim (2009) yang menyatakan bahwa individu yang memiliki tingkat IBT yang lebih tinggi kemungkinan mengalami lebih banyak desakan untuk 
membeli secara spontan dan perilaku tersebut cenderung berulang.

\subsubsection{Pengaruh Afektif Terhadap Perilaku Pembelian Impulsif}

Dari hasi penelitian didapatkan hasil bahwa variabel afektif berpengaruh signifikan terhadap perilaku pembelian impulsif. Jika aspek afektif pada diri seseorang tinggi, maka akan meningkatkan pembelian impulsif.

Pada variabel afektif, indikator pengaturan mood mengenai membeli dapat mengurangi rasa stress, merupakan item pertanyaan yang jawabannya cukup tinggi, ini artinya konsumen merasa bahwa aktivitas belanja dapat dijadikan sebuah sarana untuk mengatasi rasa stress ataupun kebosanan. Temuan ini mendukung studi terdahulu dimana item-item pembelian impulsive menjadi sebuah metode efektif untuk mengubah atau mengelola mood seperti rasa bosan, depresi, stress dan frustasi (Gardner dan Rook dalam Coley dan Burgess, 2003).

\subsubsection{Pengaruh Kognitif}

Berdasarkan hasil penelitian yang telah dilakukan, aspek kognitif diketahui berpengaruh negatif secara signifikan terhadap perilaku pembelian impulsif atau hubungan kognitif berbanding terbalik dengan pembelian impulsif. Artinya ketika konsumen lebih responsif terhadap keadaan kognitifnya, maka konsumen kurang memungkinkan untuk melakukan pembelian impulsif.

Hasil penelitian ini secara empiris sesuai dengan penelitian terdahulu yang dilakukan oleh Dawson dan Kim (2009) yang menyatakan bahwa aspek kognitif berhubungan signifikan secara negatif terhadap pembelian impulsif.

\subsubsection{Pengaruh Evaluasi Normatif}

Dari hasil penelitian didapatkan hasil bahwa evaluasi normatif berpengaruh signifikan terhadap perilaku pembelian impulsif. Jika konsumen merasa bahwa keputusan pembelian impulsif yang dilakukan merupakan keputusan yang tepat maka konsumen akan meandang pembelian impulsif sebagai perilaku yang positif dan cenderung melakukan pembelian impulsif secara berulang.

Hal ini sesuai dengan penelitian yang dilakukan oleh Rook dan Fisher (1995) dan Dawson dan Kim (2009) yang menyatakan bahwa konsumen hanya melakukan pembelian impulsif ketika mereka merasa keputusan yang dibuat tepat.

5.7.8. Variabel Afektif sebagai variabel dominan dalam perilaku pembelian impulsif

Berdasarkan hasil penelitian dapat diketahui bahwa variabel afektif merupakan variabel yang berpengaruh dominan dalam memicu timbulnya perilaku pembelian impulsif. Dapat simpulkan bahwa perilaku pembelian impulsif yang dilakukan oleh seorang konsumen sangat tergantung dari bagaimana kecenderungan atau kepribadian konsumen itu sendiri, bagaimana suasana hati atau perasaan yang melekat pada konsumen ketika melakukan aktivitas belanja (Coley dan Burgess, 2003).

Hasilnya menunjukkan beberapa implikasi bagi pihak industri. Emosi pembelian yang positif dan pengelolaan mood adalah komponen yang paling signifikan dari proses afektif, usaha-usaha retailer atau pemasar dalam menciptakan strategi eksternal yang efektif tidak boleh diabaikan. Retailer harus terus-menerus bekerja untuk menciptakan lingkungan belanja yang positif dan menyenangkan.

\subsection{Implikasi Penelitian}

Hasil penelitian ini dirasa dapat memberikan kontribusi akademis dan memperluas studi mengenai penggunaan isyarat eksternal dan internal ke dalam konteks berbelanja impulsif. Dari perspektif manajerial, hasil penelitian ini menunjukkan bahwa isyarat eksternal dan internal dapat memicu keinginan konsumen untuk melakukan pembelian impulsive. Oleh karena itu pihak pemasar dan retailer dapat menggunakan informasi mengenai konsep isyarat pemicu eksternal dan internal dalam membantu memenuhi 
kebutuhan dan keinginan konsumen, mengembangkan strategi pemasaran efektif agar mendorong pembelian impulsive lebih banyak lagi. Dengan demikian retail atau toko akan mampu meningkatkan profitabilitas.

\subsection{Keterbatasan Penelitian}

1. Studi ini dibatasi pada sampel mahasiswa dua perguruan tinggi di kota Malang, maka perlu untuk mereplikasi studi ini dengan menggunakan sampel konsumen diluar mahasiswa, sehingga akan diperoleh karakteristik pembeli impulsif yang lebih luas dan beragam.

2. Penelitian ini dibatasi hanya menggunakan sampel mahasiswa yang tidak dibedakan secara gender. Padahal Perilaku konsumen perempuan secara umum dianggap lebih berakar secara emosional dan psikologis dibandingkan laki-laki, yang menunjukkan bahwa perempuan lebih rentan terhadap pembelian impulsif.. Perbedaan gender antar pembelanja merupakan kepentingan yang besar bagi sebuah perusahaan untuk membuat strategi efektif agar mendapatkan target konsumen lebih tepat dan lebih baik.

3. Hasil penelitian ini tidak bisa digeneralisir. Hal ini dikarenakan responden penelitian dipilih berdasarkan karakteristik seperti yang telah disebutkan dalam populasi target dan penelitian ini bersifat lokal yakni hanya dilakukan di kota Malang.

4. Variabel isyarat pemicu internal dalam penelitian ini hanya empat yaitu, IBT, afektif, kognitif dan evaluasi normatif, belum memasukkan variabel demografis untuk memperkaya temuan tentang pengaruh variabel internal terhadap pembelian impulsif.

5. Beberapa kuisioner atau angket yang disebarkan tidak mendapat respon yang baik dari kalangan mahasiswa, kemudian ada pula beberapa angket yang diabaikan atau dieliminir karena datanya tidak sesuai dengan kriteria penelitian yang telah ditetapkan.

\section{KESIMPULAN DAN SARAN}

\subsection{Kesimpulan}

Kesimpulan yang diperoleh dari penelitian mengenai pengaruh variabel eksternal dan internal terhadap perilaku pembelian impulsif mahasiswa di kota Malang adalah sebagai berikut :

1. Stimulus marketing mix, atmosfer dalam retail, IBT atau kecenderungan pembelian impulsif, afektif, kognitif, dan evaluasi normatif mampu meningkatkan perilaku pembelian impulsif mahasiswa. Konsumen lebih termotivasi untuk melakukan pembelian impulsif jika pihak retailer atau pemasar dapat merancang strategi pemasaran yang efektif dan mampu menciptakan lingkungan belanja yang positif untuk mempengaruhi suasana hati atau mood konsumen ketika melakukan aktivitas belanja.

2. Stimulus marketing mix, IBT atau kecenderungan pembelian impulsif, afektif, kognitif dan evaluasi normatif mampu meningkatkan perilaku pembelian impulsif mahasiswa. Khususnya untuk atmosfer dalam retail tidak memberikan dampak pada pembelian impulsif, ini disebabkan karena konsep interior dan kenyamanan toko atau retail yang dirancang dengan baik oleh pihak retailer atau pemasar tanpa diimbangi dengan strategi penetapan harga produk yang sesuai dengan kemampuan sumberdaya keuangan mahasiswa yang terbatas, tidak akan memberikan dampak pada level pembelian impulsif. 
3. Afektif merupakan penentu yang dominan dalam perilaku pembelian impulsif. Konsumen yang lebih rentan terhadap emosi atau keadaan afektif ditemukan lebih mungkin mengalami dorongan untuk membeli secara impulsif.

\section{DAFTAR PUSTAKA}

Alex Sobur. 2003. Psikologi Umum. CV. Pustaka Setia. Bandung.

Agoes Dariyo. 2003. Psikologi Perkembangan Dewasa Muda. Penerbit PT. Grasindo. Jakarta.

Bayley Geoff dan Nancarrow Clive. 1998. Impulse purchasing: a qualitative exploration of the phenomenon. Qualitative Market Research: An International Journal. Volume 1 No. 2 .pp 99-114

Beatty, S. E. dan Ferrel, M. E. 1998. Impulse Buying : Modelling it's Precursors. Journal of Retailing. Volume 74 No.2. pp, 169-97.

Bellenger, D.N, Robertson, D.H, dan Hirschman. E.C. 1978.I mpulse buying varies by product. Journal of Advertising Researchi, Volume 18 No. 6. pp, 15-18.

Coley, Amanda dan Burgess Brigitte. 2003. Gender Differences in Cognitive and Affective Impulse Buying. Journal of Fashion Marketing and Management. Volume 7 No. pp, 282-295.

Dholakia, U.M. 2000. Temptation and resistance: an integrated model of consumption impulse formation and enactment. Psychologi and marketing Journal. Volume 17 No. 11. pp, 95582

Dittmar H., Beattie, J. dan Friese, S. 1995. Gender Identity and Material Symbols: Objects and decision Considerations in Impulse Purchases. Journal of Economic Psychology. Volume 16 No. 3. pp, 491-551.
Engel, J.F., Blackwell, R. D., dan Miniard, P. W. 2000. Consumer Behavior $\left(6^{\text {th }}\right.$ edt). Washington : Holt, Rinehart and Winston, inc.

Erna Ferrinadewi. 2008. Merek dan Psikologi Konsumen : Implikasi pada Strategi Pemasaran. Graha Ilmu. Yogyakarta.

Fireman, S. 1999. Marketing: Manager Update. Volume 10 No. 4. pp, 1221.

Ferdinand, Augusty. 2006. Metode Penelitian Manajemen : Pedoman Penelitian untuk Penulisan Skripsi, Tesis dan Disertasi Ilmu Manajemen. Penerbit UNDIP. Semarang.

Ghozali, Imam. 2006. Aplikasi Analisis Multivariate dengan Program SPSS.. Penerbit UNDIP. Semarang.

Gujarati, Damodar. 2005. Ekonometrika Dasar. Erlangga. Jakarta

Hausman, A. 2000. A Multi Method Investigation of Consumer Motivation in Impulse Buying Behavior. Journal of Consumer Marketing. Volume 17 No. 15, pp. 403-419.

Hendri Ma'ruf. 2005. Pemasaran Ritel. Penerbit PT. Gramedia Pustaka Utama. Jakarta.

Hurlock, Elizabeth. 1980. Psikologi Perkembangan : Suatu Pendekatan Sepanjang Rentang Kehidupan. Edisi kelima. Penerbit Erlangga. Jakarta.

Kacen, J.J. dan Lee, J.A. 2002. The influence of culture on consumer impulsive buying behaviour. Journal of Consumer Psychology, Volume. 12 No. 2, pp. 163-76.

Kasali, Rhenald. 2005. Membidik Pasar Indonesia : Segmentasi, Targeting dan Positioning. Penerbit PT. Gramedia Pustaka Utama. Jakarta.

Kotler. P. 2000. Manajemen pemasaran. Edisi millenium 1. (Hendra Teguh, 
Ronny Antonius Rusli, dan Benjamin Molan). PT. Prenhallindo. Jakarta.

Maholtra, N. K. 2005. Riset Pemasaran : Pendekatan Terapan. PT. Indeks. Jakarta.

Park, E. J., Kim, E. Y., dan Forney, J.C. 2006. A Structural Model of Fashion -Oriented Impulse Buying Behavior. Journal of Fashion Marketing and Management. Volume 10 No.4, pp. 135-141.

Park, H. J., dan Burns L. D. 2005. Fashion Orientation, Credit Card Use and Compulsive Buying. Journal of Consumer Marketing. Volume 22 No. 3, pp. 135-141.

Phau, Ian dan Woo, Charise. 2008. Understanding compulsive buying tendencies among young Australians : The roles of money attitude and credit card usage. Journal of Marketing Intelligence \& Planning. Volume. 26 No. 5, pp. 441-458.

Prastiwi Alivia. 2007. Perilaku pembelian impulsive produk pakaian pada mahasiswi di kota Malang. Univ Brawijaya. Malang.

Rook, D. W., dan Fisher, R. J. 1995. Normative Influences on Impulsive Buying Behavior. Journal of Consumer Research. Volume 22 No 3, pp. 305-13.

Sandy Dawson dan Minjeong Kim. 2009. External and internal trigger cues of impulse buying online. Journal Direct Marketing: An International. Volume. 3 No. 1, pp. 20-34.

Schiffman, L dan Kanuk, L. L. 2007. Perilaku Konsumen. PT. Indeks. Jakarta.

Solomon, Michael, R. 2002. Consumer Behavior. 5 th Edition. Prentice Hall, Inc. New Jersey.
Stanton, J. William dan Futrell. 1987. Fundamental of marketing. McGraw-Hill, Inc. New York.

Sugiyono. 2002. Metode Penelitian Bisnis. CV. Alfabeta. Bandung.

Syamsu Yusuf. 2001. Psikologi Perkembangan Anak dan Remaja. PT. Remaja Rosdakarya. Bandung.

Thompson, Craig J., William B. Locander, and Howard Pollio 1990. The Lived Meaning of Free Choice: An Existential-Phenomenological Description of Everyday Consumer Experiences of Contemporary Married Women. Journal of Consumer Research. pp. 346-361.

Tri Dayakisni dan Hudaniah. 2003. Psikologi Sosial. UMM Press. Malang.

Tulus Winarsunu. 2004. Statistik dalam Penelitian Psikologi dan Pendidikan. UMM Press. Malang.

Weekes, T. 2004. Spending on Clothing and Attitudes to Debt in the UK. Journal of Fashion Marketing and Management. Volume 8 No.1, pp. 113-122.

Youn, S.H. (2000). The dimensional structure of consumer buying impulsivity: measurement and validation.

Youn, S. H., dan Faber R. J. 2000. Impulse Buying : its Relation to Personality Traits and Cues. Advances in Consumer research. Volume 27, pp 179-85. 